BUILDINGS ARCHAEOLOGY 


\title{
THE EARLY BYZANTINE DOMED BASILICAS OF WEST ASIA MINOR. AN ESSAY IN GRAPHIC RECONSTRUCTION
}

\author{
Nikolaos D. Karydis
}

\begin{abstract}
This paper investigates the methodology employed in the recent survey and reconstruction of the major Early Byzantine domed churches of western Asia Minor. This involved both the documentation of construction details, as well as their interpretation by reference to coeval monuments elsewhere. Focusing on this methodology, the author explores techniques of graphical recording and the theoretical framework within which parallels with other buildings can inform the work of reconstruction. The detailed examination of two case studies illustrates the way in which seemingly random scraps of testimony can be interpreted to provide evidence for the missing superstructure of ruined churches. These case studies also serve to demonstrate how the methodology adapts to sites with different characteristics, and helps to assess the credibility of the resulting graphic reconstructions.
\end{abstract}

\section{INTRODUCTION}

The break from the tradition of timber-roofed basilicas to vaulted church construction is one of the most intriguing architectural developments of Late Antiquity. It also plays a major role in the history of ecclesiastical architecture, as it generated forms and structures that were to have a lasting and far reaching influence on the way churches were built during the Middle Ages. The early stages of this development seem to date back to the period between the late $5^{\text {th }}$ and the $7^{\text {th }}$ c., and some of its earliest manifestations occur in the vaulted monuments of Constantinople and west Asia Minor. If the former are well-studied, the role of western Asia Minor in the development of vaulted church architecture is often underestimated, despite the publications of A. Choisy, H. Buchwald, and others on this topic. ${ }^{1}$ As these two authors have shown, numerous remains of

1 Choisy (1883) 162; Buchwald (1984) 200-34. 
domed churches attributed to the Early Byzantine period make the area of west Asia Minor one of the geographical centres of this development.

The cities of Ephesus, Sardis, and Philadelphia preserve the ruins of some of the earliest and most sophisticated vaulted churches. The churches of St. John and St. Mary at Ephesus, Building D at Sardis and St. John at Philadelphia, to mention only the main examples, occupied central urban locations, either replacing earlier timber-roof basilicas, as in Ephesus, or major pagan monuments, as in Sardis. ${ }^{2}$ The construction of at least eight ambitious vaulted churches, at a time when ecclesiastical architecture was still dominated by the model of the timber-roof basilica, is rare outside western Asia Minor, and indicates that this region was a major creative centre in Late Antiquity. ${ }^{3}$ But, these churches are not only relevant for the study of late antique architecture. Some of them seem to have been in use for many centuries after their construction, acting as centres of urban life, and so constituting a 'golden thread' connecting the end of Antiquity with the Middle Ages. ${ }^{4}$ The durability of these monuments in an earthquake-prone area like western Asia Minor also represents a remarkable feat of structural engineering. ${ }^{5}$

Despite their historical significance, architectural value, and structural merit, these vaulted churches are not adequately represented in the standard textbooks of Byzantine architecture. ${ }^{6}$ The architectural type of the 'multi-domed basilica', to which most of these churches belong, is often overlooked. One of the reasons for this is the poor preservation of these monuments. The decay and loss of their magnificent vaulted canopies makes it difficult to appreciate the particular spatial experience that made them unique (fig. 1). To recapture this experience one needs to visualise

2 Foss (1979) 96, looks at the churches of Ephesus in their urban context and refers to all the excavation reports and studies up to that time. More recent and detailed surveys can be found in Thiel (2005), for the church of St. John at Ephesus, and Karwiese (1999) 81, for the church of St. Mary in the same city. The church known as 'Building D' in Sardis was recently published by Karydis (2012b) 115. For a survey of the church of St. John at Philadelphia, see Buchwald (1981) 301.

3 Indeed, according to Mango (1978) 58, timber-roof basilicas constituted the vast majority of churches that were put up in the 6th c. The Early Byzantine development of vaulted church architecture is not only observed in the west coasts of Asia Minor, but also in Cilicia. Still, the materials and forms employed there are somewhat different from the ones used in western Asia Minor. For the Early Byzantine church architecture of Cilicia, see: Gough (1968) 455-64, and Iacobini (2003-2004) 135-74.

4 Foss (2002) 132, for example, highlights the role of the church of St. John at Ephesus as one of the most important pilgrimage sites during the Middle Ages.

5 For the seismic activity of the area, see Altunel (2000) 299.

6 Krautheimer (1986) 258-82; Mango (1978) 86-88. 


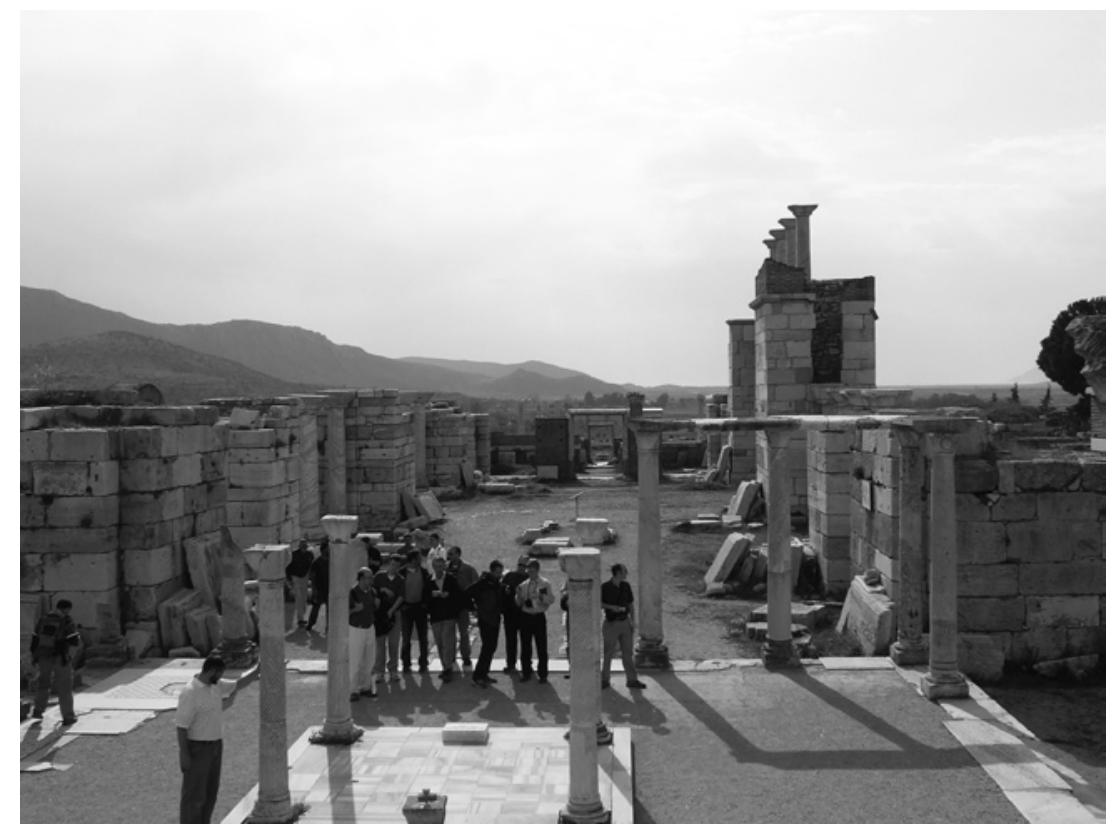

Fig. 1. Ephesus, church of St. John, view of the nave from the crossing.

original forms on the basis of very limited remains, which is quite a difficult and complex task. In some cases, as for instance in the two churches of Ephesus, scholars have attempted to recapture the complete form of the monuments with reconstruction drawings. ${ }^{7}$ Still, until recently, this was done on a tentative basis, and led to hypotheses that were not adequately substantiated. ${ }^{8}$ The investigation of the church of St. John at Ephesus is typical of this phenomenon: the great differences between the graphic reconstructions carried out by H. Hörmann in 1951 and A. Thiel in 2005 compromise their credibility, creating the impression that there are infinite reconstruction possibilities.

The failure to provide evidence for the reconstructions in these studies should not be seen as the fatal result of advanced dilapidation, after all, not all the evidence has disappeared. One of the most important limitations

7 For St. John at Ephesos, see: Hörmann et al. (1951) 165-69, figs. 42, 44, tables LXIX, LXX; Thiel (2005) 110. For St. Mary at Ephesos, see Knoll (1932) 62.

8 For instance, Plommer (1962) 124, has challenged Hörmann's reconstruction of the church of St. John at Ephesos, and Fasolo (1956) 12 has revised Knoll's reconstruction of the church of St. Mary at Ephesos. 
in past efforts has been the tendency to overlook, or misinterpret, surviving structural details that can provide significant clues for reconstruction. Based on this realisation, the author made the detailed documentation of the structural fabric of these churches the main purpose of fieldwork carried out in 2007 and 2008, which was published in $2011 .^{9}$ This work revealed a series of unexplored fragments of vaulting that had escaped notice before. The interpretation of these fragments, based on references to similar details in a wide range of contemporary monuments, provided essential evidence for the reconstructions. This 'hybrid' methodology, which was based both on careful site observation and comparative interpretation, helped to construct new, plausible models for the original form of the churches.

What makes these new 'models' plausible is not their graphic presentation, but the method of site observation on which they are based. Indeed, at a time when photo-realistic visualisation is omnipresent everywhere, from best-selling guidebooks to scholarly volumes, the author's reconstruction drawings may seem rather too technical and abstract by comparison (fig. 2). ${ }^{10}$ Instead of trying to visualise original forms in all their ornamental detail, most of which has been lost forever, these drawings privilege the investigation of those structures and forms that can still be recovered. These are presented very simply, not with perspective views, but with a type of cut-away axonometric drawing characteristic of the work of A. Choisy. ${ }^{11}$ Compared with perspective views, such axonometric diagrams are less successful in conveying spatial experience and character. Still, they are more efficient in analysing structural form. What makes these graphic reconstructions convincing, despite their abstract and rudimentary presentation, is the methodology on which they are based and the latter's two components: site observation and interpretation of archaeological evidence.

The present article offers an opportunity to clarify both aspects of this methodology. It investigates the way in which construction details were documented and drawn, and examines how comparisons between farflung structures helped to interpret obscure construction details. This is followed by two case studies: the reconstruction of the churches of St. John and St. Mary at Ephesus. These case studies illustrate the way in which the methodology was adapted to the different conditions of each monument,

\footnotetext{
9 Karydis (2011) 67.

10 For some interesting comments on a wide range of approaches to graphic reconstruction, see: Gros (2002) 11, as well as Greenewalt et al. (2003) 85-120.

11 Choisy (1883). For an analysis of Choisy's methodology, see Huerta (2009) 289-305.
} 


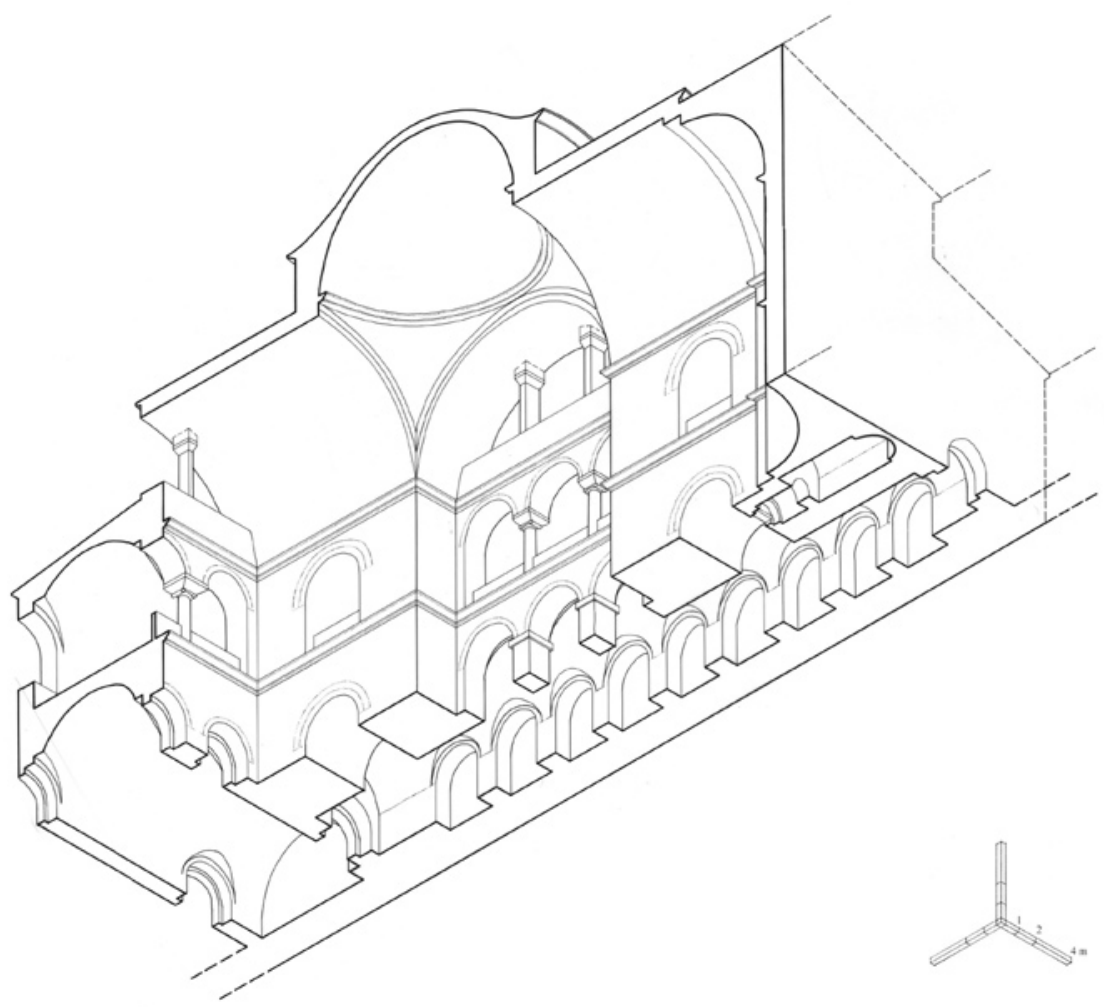

Fig. 2. Ephesus, church of St. Mary, domed church, reconstructed axonometric.

and particularly to its different state of preservation. Analysing this methodology is essential in order to establish the degree to which its results can be considered conclusive, and to evaluate the scope of its use elsewhere. But, before we examine past and potential future uses of this methodology, a few preliminary words are necessary to examine the procedures involved.

\section{GRAPHIC RECORDING AND INTERPRETATION}

The study of the monuments started with the study of their plans. ${ }^{12}$ Soon, it became apparent that redrawing these plans did not only allow

12 In the cases of the churches of Ephesus, Sardis, Philadelphia and Hierapolis, measured plans had already been published by Hörmann (1951) for St. John at Ephesus, Knoll (1932) for St. Mary at Ephesus, Buchwald (1981) for St. John at Philadelphia, and Verzone 

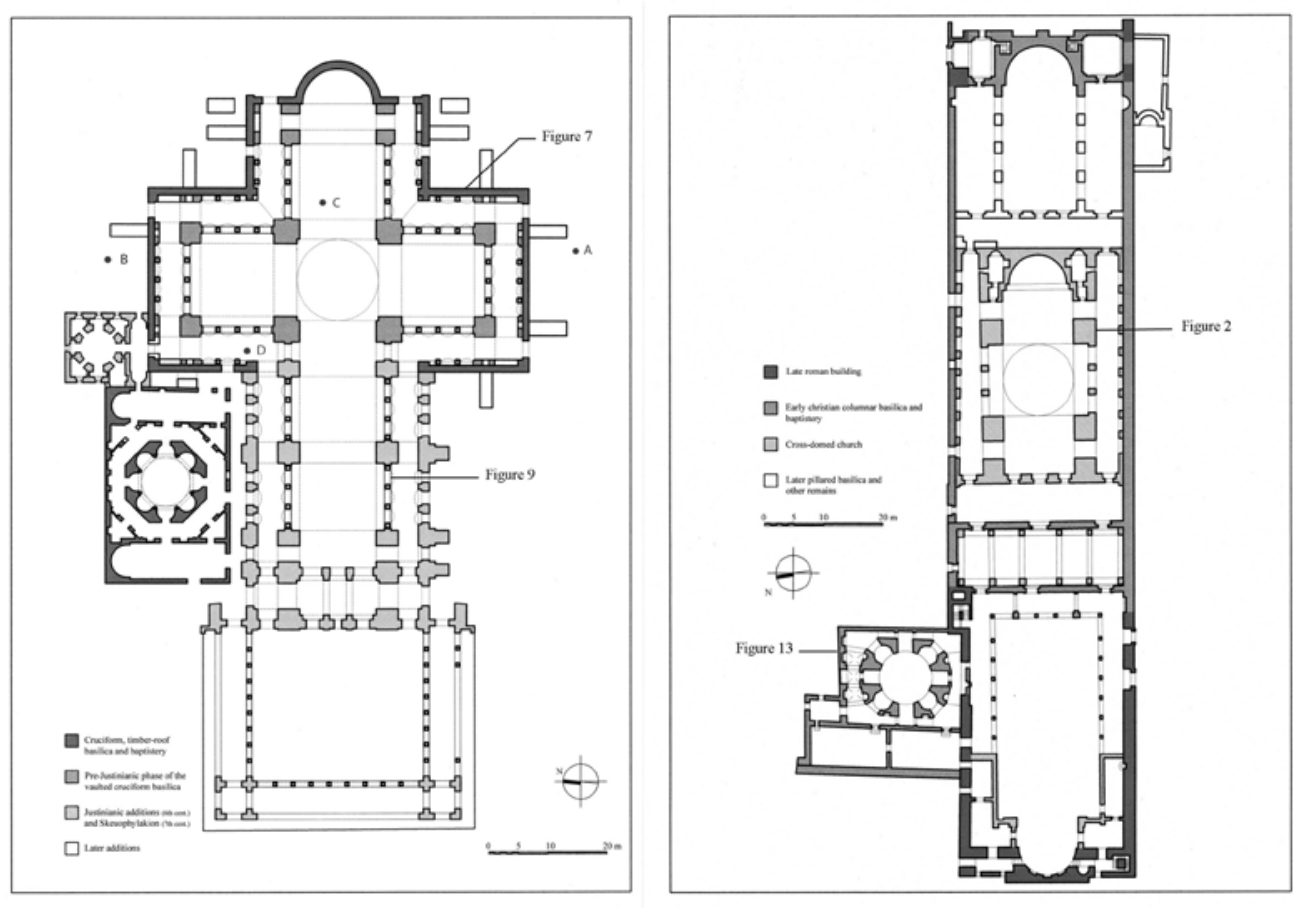

Fig. 3. Ephesus, churches of St. John (left) and St. Mary, plans of the remains showing building phases, as well as the areas of the plan that correspond to the reconstruction of the vaults in figures $2,7,8$, and 13 .

for a coherent exploration of the chaotic remains, but this process also provided clues for establishing missing vaulting patterns (fig. 3). For instance, the division of naves into square or oblong bays tended to suggest that the ceilings were also compartmentalised into a series of smaller vaults. The sizeable niches surrounding the bays reflected the existence of broad arches surrounding spherical vaults. Pier profiles were also observed. ${ }^{13}$ Their re-entrant angles and projections corroborated the existence of broad arches between the bays. Finally, the oblong bay shape in certain churches was deemed more compatible with 'pendentive domes'

(1956) for the churches of Hierapolis. In the case of Sardis, the plan of Building D was made available by the archaeological expedition of Sardis. Finally, in the case of Pythagorion, on the island of Samos, the author drew a plan based on his own survey.

13 For a convincing interpretation of the pier profiles of the church of Dağ Pazarı, as indirect evidence for the reconstruction of the vaults, see Iacobini $(2003-2004) 150-52$. 
(fig. 8), rather than with 'full domes on pendentives'; pendentives being the triangular section of vaulting between the base of the dome and the arches that support it. Full domes on pendentives can only be constructed on top of four arches of the same height, something difficult to achieve in an oblong bay, where the diameters of the side arches vary. Also, a pendentive dome constitutes a continuous spherical surface, and the absence of visible transition between pendentive and cupola makes this type of vault particularly adaptable to an oblong bay. An observation noting the use of pendentive domes in a wide range of surviving Early Byzantine monuments, confirmed this. ${ }^{14}$

These preliminary observations were tested through free-hand reconstruction sketches, some of which are published here for the first time (fig. 4). Certain sketches constituted first attempts towards overall reconstructions, whereas others illustrated hypotheses about parts of the original structure. These sketches, of course, were entirely hypothetical. Some of them, as for instance the schematic reconstruction of the pillar basilica at Hierapolis, were to be contradicted by later discoveries. However, these sketches helped to familiarise the author with the forms under investigation, and paved the way for the more detailed documentation that was to follow.

Early experimentation with plans and reconstruction sketches directed the survey towards construction details that offered more solid evidence for the missing superstructure. The survey revealed vault fragments that had not been investigated before, perhaps because of a difficulty with their interpretation. In most monuments, these fragments had been either misinterpreted or dismissed as amorphous masses of mortar and brick..$^{15}$ Still, their careful study constitutes an excellent basis for reconstruction. The investigation of these overlooked elements started from on-site graphical recording. Cut-away axonometric drawings in 1:50 scale, showing simultaneously the horizontal and vertical disposition of the fragments, and proved to be the best medium for analysis (fig. 5). The latter documented

\footnotetext{
14 For the geometrical definition of the pendentive dome, and a brief survey of its use in Early Byzantine architecture, see Ćurčić (1992) 28.

15 Hörmann et al. (1951) 92, who surveyed the vault fragments of the church of St. John at Ephesus, is a notable exception here. However, Hörmann did not manage to establish convincing links between the fragments he surveyed and the original structure. A more recent attempt to interpret structural fragments as evidence for graphic reconstruction was made by Iacobini (2003-2004) 153. However, in this case, the survey relied on photos of the fragments, as opposed to detailed drawings, which limits the interpretation.
} 

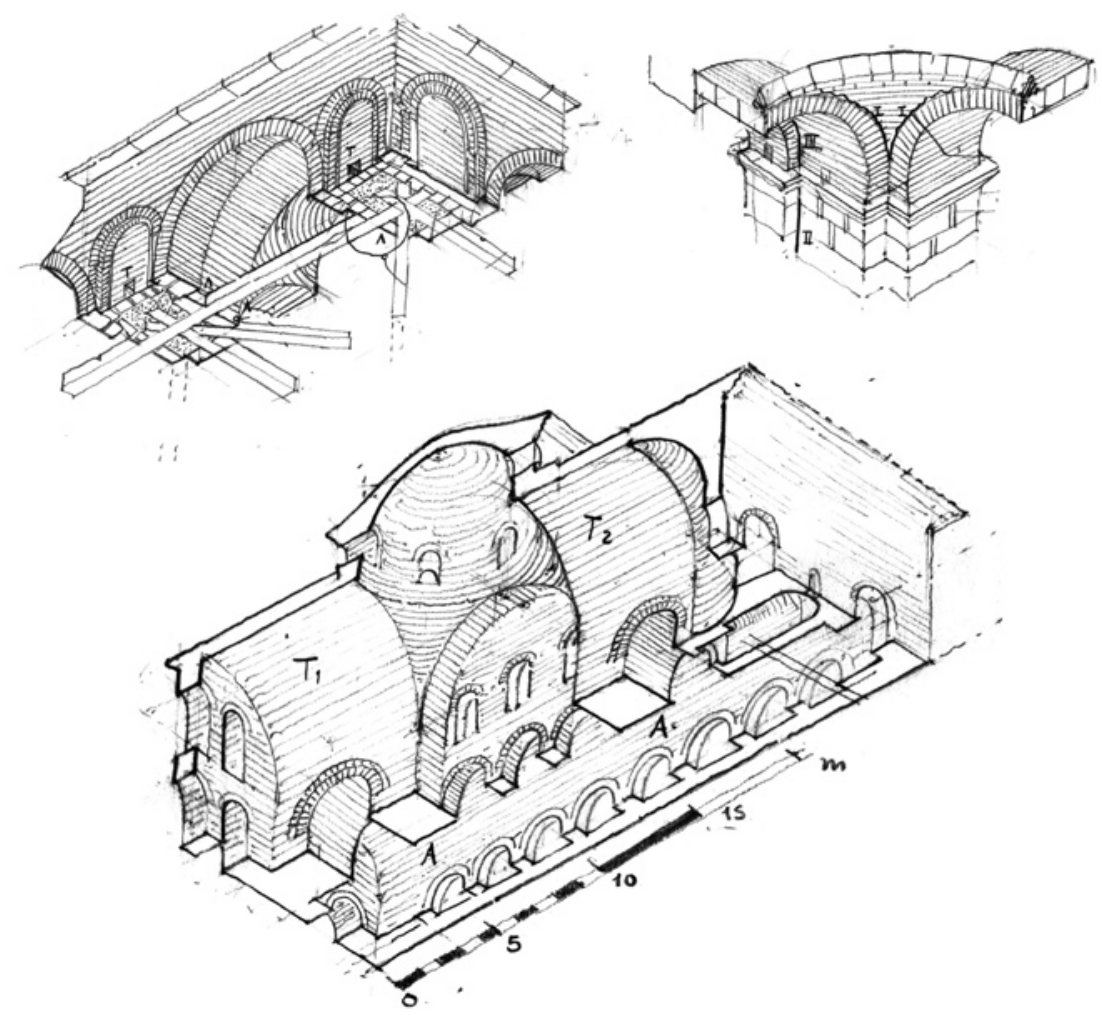

Fig. 4. Philadelphia, church of St. John (top) and Ephesus, church of St. Mary, domed church, preliminary reconstruction hypotheses.
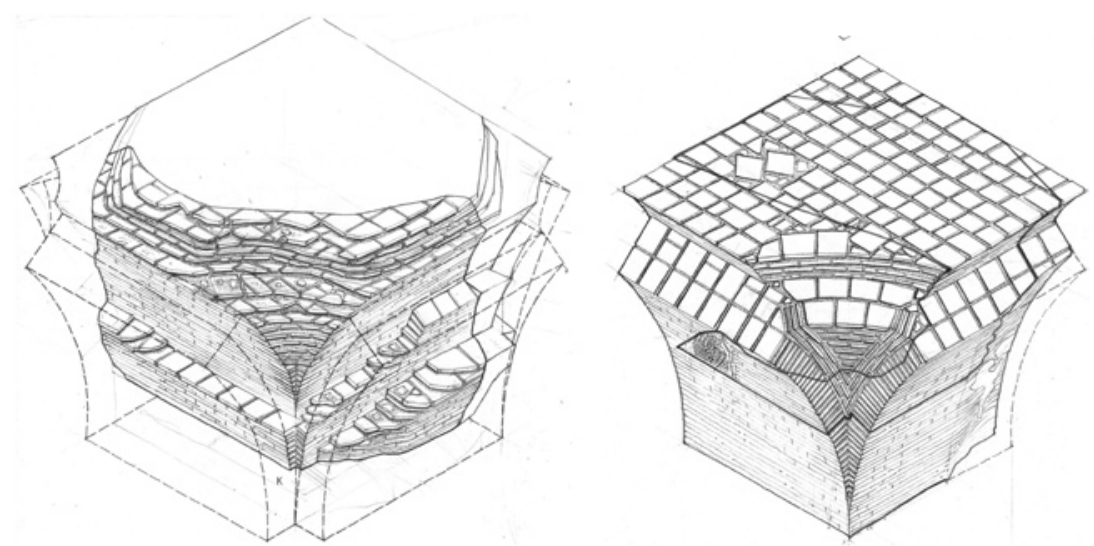

Fig. 5. Ephesus, church of St. John, fragments of the vault over the crossing (left) and the vault over the south bay of the transept (right). 
both the overall form of the fragments and the way the bricks were set. It also sought to establish the exact role of each fragment in the original structure. Consultation of the schematic diagrams prepared in the first stage was essential in contextualising these fragments, even though, in some cases, this led to a revision of preliminary hypotheses.

But, at this stage, a problem emerged. It turned out that all the fragments were at the level of the springing of arches and pendentives. Indeed, not a single fragment from the crown of the vaults had survived. Consequently, it seemed impossible to establish whether the fragments belonged to pendentive domes or to domes on pendentives, as the difference between these types of vault manifests itself mainly in their upper layers. Comparisons with a wide range of coeval structures elsewhere played a major role in surmounting this problem, making it possible to deduce the form of the complete superstructure on the basis of these low-level fragments. Chiefly by reference to contemporary monuments in Constantinople, it was shown that the specific connection between a pendentive and the broad arches is a good indicator for the overall form of the vault, and can help to distinguish pendentives that carried a shallow dome from the ones carrying a full dome. Following this discovery, the reconstruction of entire domes was based on the observation of the few surviving low courses of their pendentives, and the particular way in which these courses met the supporting arches.

The original forms that emerged in this way were represented graphically with cut-away axonometric drawings. In most of these drawings, and at least in one drawing per monument, care was taken to distinguish parts that still survive from the ones that were being reconstructed. The author experimented with various graphic media to achieve this. In some cases, the reconstructed parts were shown in less detail and with dashed lines. In other cases the existing parts were highlighted with a red outline.

The previous paragraphs show that a series of different and complementary methodological tools were employed. However, the combined use of these tools for one monument has not always been possible. Even when reconstruction relied both on graphic recording and formal comparisons, the two methods were not always equally fruitful. With certain monuments, reconstruction had to rely on only a partial use of this methodology. The ways in which the above methods were adapted to the conditions of each site are clear from the case studies that follow. 


\section{Case Studies}

\section{St. John at Ephesus}

The author's reconstruction of the church of St. John at Ephesus provides the most complete illustration of the above methodology. The processes outlined above made it possible to fill important lacunae in our understanding of a major Early Byzantine monument. Indeed, ever since the first excavation of the remains of the church of St. John, the reconstruction of the vaulted, 6th c. phase of the monument has been one of the main aims in the field of Early Byzantine architectural studies. This is partly due to the historic significance of the building. The church, rebuilt and enlarged under the auspices of the Emperor Justinian, constituted the Ephesian counterpart to the Constantinopolitan church of the Holy Apostles. ${ }^{16}$ Situated on the fortified hill of Ayasoluk, it was later to become the 'heart' of medieval Ephesus, and one of the most important pilgrimage churches in Asia Minor. ${ }^{17}$ In spite of several attempts to recapture the form of this church, and although its walls and supports largely survive, the form of the vaults remained conjectural until recently. The diversity of ways in which these vaults have been reconstructed during the last fifty years echoes the limited evidence available. The proposals of H. Hörmann, P. Verzone, M. Büyükkolancı, and A. Thiel have explored several different possibilities. ${ }^{18}$ An examination of these proposals leaves us with a dilemma: should we see the main vaults of the church as a series of domes on pendentives, or pendentive domes. None of these proposals have offered conclusive evidence for either of these two vault forms.

The author's recent survey showed that the evidence for the vaults has not been entirely lost. Site observation revealed vault fragments whose potential as evidence for reconstruction had until now been underestimated. This evidence came from two distinct groups of vault fragments. The first group includes fallen fragments that survive on site. These belong to the vaults of the transept, and had never been recorded before. The second group consists of fragments that came from the vaults of the nave, which were irresponsibly destroyed during the course of the building's excavation.

16 As attested in the 6th c. by Procopius of Caesarea: Procop. Aed. 5.1.4-7.

17 Foss (2002) 132.

18 Hörmann et al. (1951) 165-69, fig. 4; Verzone (1965) 6o9; Büyükkolancı (2000) 51; Thiel (2005) 42-48, 110. 
Investigation of this evidence started from drawings. This established that all these fragments came from the springing of arches and pendentives. At first sight, the fragments appeared to be identical, but careful recording revealed that the connection between the arch and the pendentive varied. In the fragments of the vault over the crossing, the pendentive sprung from the extrados of the broad arches. In all the other fragments, the pendentive lay on the sloping face of the arches (cf. Fig. 5).

This observation helped to interpret these details. This was facilitated by the study of similar elements in two surviving coeval monuments: Hagia Sophia and St. Eirene at Constantinople. ${ }^{19}$ These churches include both hemispherical and shallow domes. Their investigation revealed that the connection between arches and pendentives can indicate whether the latter are surmounted by a shallow dome or a full, hemispherical dome. Pendentives that carry a full dome tend to connect to the extrados of the supporting arches. Conversely, pendentives surmounted by a shallow dome (i.e. a dome co-spherical with them) tend to spring from a skewback on the face of the arches (fig. 6).

This conclusion constituted an important step towards the interpretation of the fragments observed in St. John's. As we saw, in the transept arms and the nave, the pendentives sprang from the sloping face of the supporting arches. This detail is typical of pendentive domes. In the crossing, where the pendentives rest on the extrados of the arches, the vault was a hemispherical dome on pendentives. This realisation allowed for a reconstruction of the main vaults of St. John. A hemispherical dome on pendentives surmounted the crossing. It is very likely that this dome had a fenestrated drum similar to the ones from other major Justinianic churches, but, unfortunately, no part of such a drum seems to have survived. The bays of the cross-arms had lower pendentive domes (fig. 7). ${ }^{20}$

A similar methodology was employed for the reconstruction of secondary vaults, such as the ones over aisles and galleries. A comparison between the scanty remains of aisle vaults with fragments of gallery vaults, revealed a morphological difference between the two vaults that had been overlooked in previous reconstructions. The difference is found both in the steepness of the profile of the vaults and in their connection

\footnotetext{
19 An excellent survey of the vaults of St. Eirene can be seen in George (1913) 44. For the spherical vaults of Hagia Sophia, see Mainstone (1988) 78, figs. 67, 134, 137 .

20 For further details about this reconstruction, see Karydis (2012a) 548.
} 

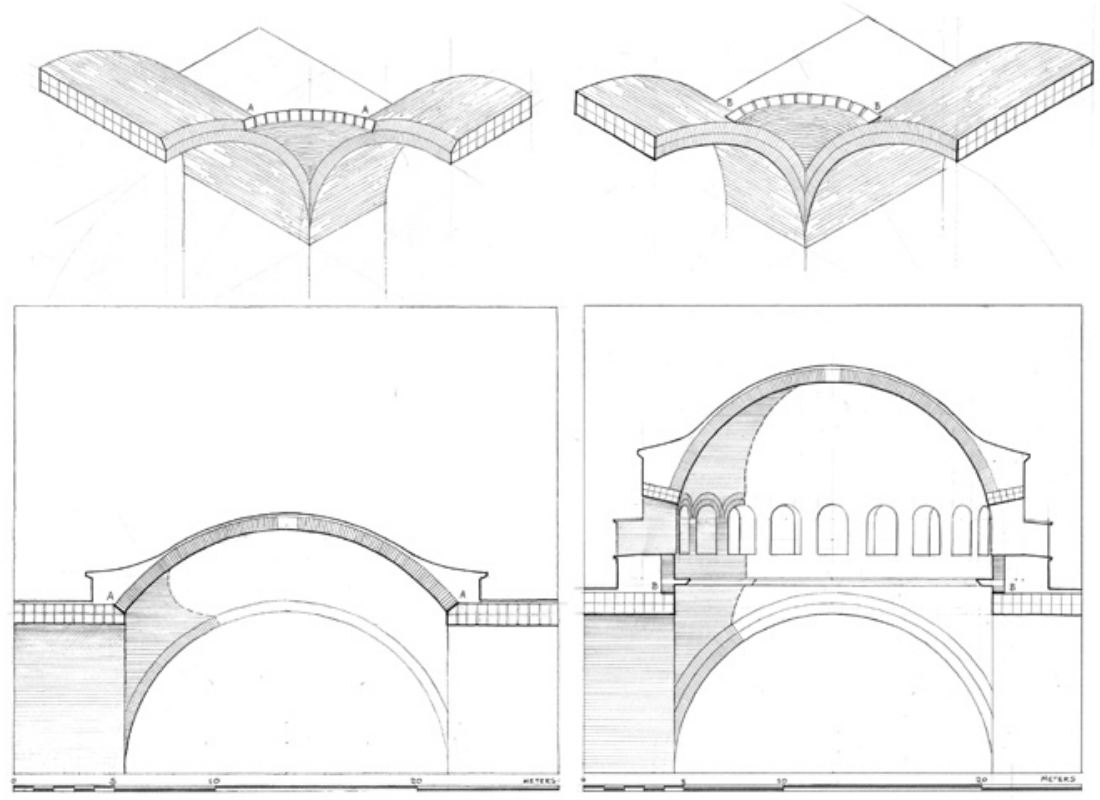

Fig. 6. Constantinople, church of St. Eirene, sections of spherical vaults and details of their springing.

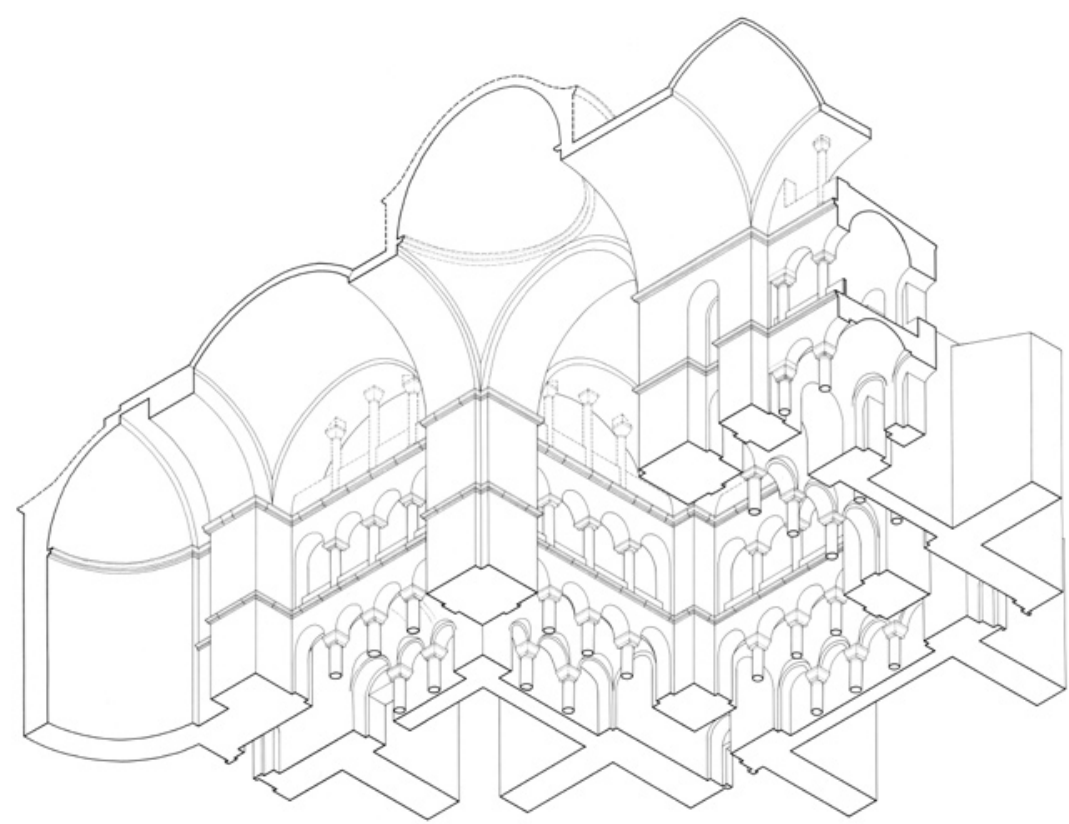

Fig. 7. Ephesus, church of St. John, reconstructed axonometric. 
with the supporting arches. It was established that the aisles were covered by barrel vaults that sprung from the same level as the arches. However, the gallery vaults had a steeper profile, springing from a level that corresponds to the crown of the arches. Similar differences between aisles and galleries are attested in a wide range of Early Byzantine monuments, such as the church of 'Our Lady of a Hundred Gates' (Panagia Ekatontapyliani) on the island of Paros, and in the church of SS. Sergius and Bacchus in Constantinople. ${ }^{21}$

In this methodology, comparison with coeval monuments elsewhere is combined with a thorough study of construction details. Structural survey does not only provide evidence for original forms, but also helps to visualise the inner layers of the original structure. For instance, in St. John's, the examination of vault fragments revealed a major structural difference between seemingly identical vaults, namely the pendentive domes of the west cross-arm (nave) and the ones of the transept. Whereas the transept vaults were built with horizontal brick courses, the nave vaults were built with arched courses forming a pattern reminiscent of the fish scales (fig. 8). What appears to be a uniform design consists in fact of different structural patterns. Taking this difference into account in our reconstruction proved to be essential for the investigation of the building phases of the monument. However, this is the object of a forthcoming publication, so will be dealt with there. ${ }^{22}$ Closing the examination of this case study, a few words are necessary about the way in which the new reconstruction improved our understanding of the church of St. John at Ephesus in the context of Early Byzantine architecture.

So far, St. John's had been considered an unconventional church whose form marked a break with standard building techniques in the age of Justinian. ${ }^{23}$ This theory had been based on an earlier reconstruction of the church, which saw it with repetitive full domes on pendentives. ${ }^{24}$ Our revised reconstruction called for a review of this theory. What is unusual in Hörmann's reconstruction is the stark subdivision of architectural space in equal bays (fig. 9). Indeed, the use of the hemispherical dome as a modular unit, and the lack of a clear hierarchy between the vaulted

21 For a thorough survey of Hekatontapyliani, see the excellent publication of Jewell and Hasluck (1920) for the Byzantine Research Fund. For the church of Sergius and Bacchus, see Mathews (1971) 47-50.

22 Karydis (2013) 89-110.

23 Krautheimer (1986) 242.

24 Hörmann et al. (1951) figs. 42-44. 


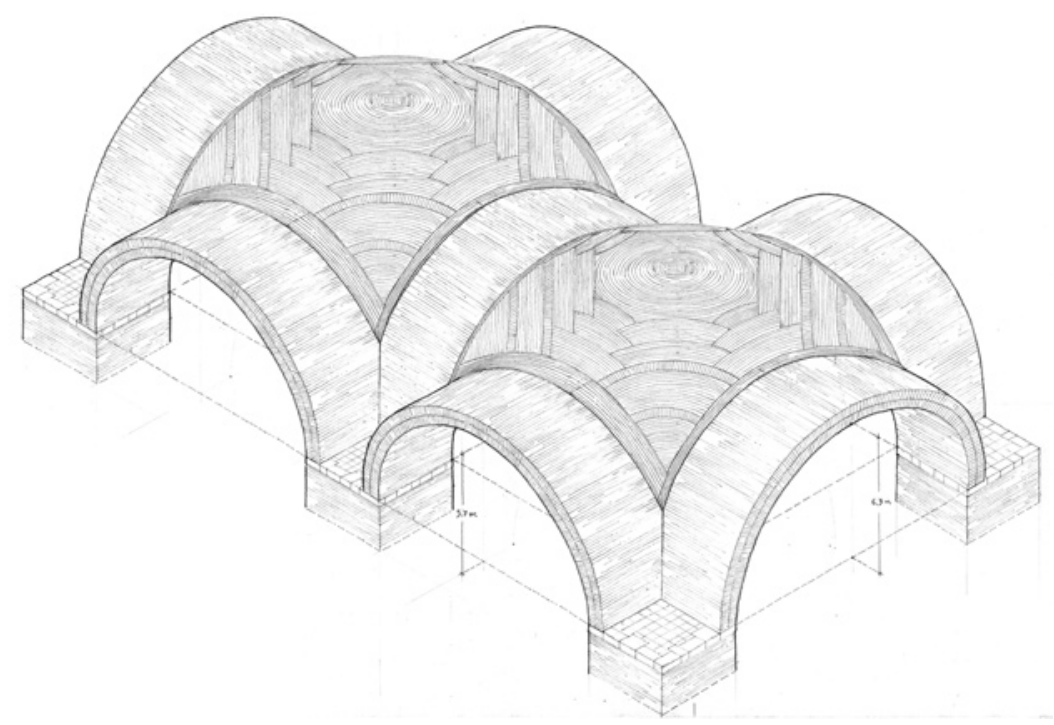

Fig. 8. Ephesus, church of St. John, reconstruction of the nave vaults.

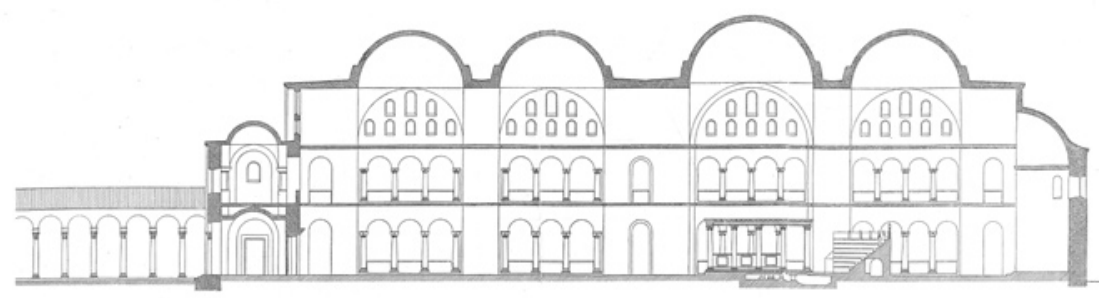

Fig. 9. Ephesus, church of St. John, reconstructed section. Drawing published in Hörmann et al. (1951).

bays, is rarely encountered elsewhere. However, these attributes are less prominent in our reconstruction. Indeed, the use of shallow as opposed to hemispherical domes in the cross-arms attenuates the segregation of the nave bays. Moreover, the solitary hemispherical dome makes the crossing the indisputable climax of the design. There are still multiple bays, but they emanate from the centre in a fluid movement, as in contemporary churches in Paros, Philippi, and Constantinople. We therefore can say that some of the principles encountered in standard Justinianic building also occur at St. John's in Ephesus as well, and the structure is not as unique as we have been led to believe. 


\section{St. Mary at Ephesus}

The complexity of the site of the church of St. Mary introduced a series of complications into the use of our reconstruction methodology. The remains of the church, which lie to the north-east of the harbour of Roman Ephesus, display all the characteristics of an architectural palimpsest. In its thousand-year history, from Roman origins to a presumed destruction some time after the 11th c., the site of the monument was repeatedly modified. It was originally the site of a long Roman building, this being transformed into an Early Christian basilica in the $5^{\text {th }} \mathrm{c}$. This phase also involved the construction of an atrium, and a baptistery north of it. Later, possibly in the 8th c., part of the basilica was transformed into a crossdomed church. For most of its history, the St. Mary's must have consisted of a cross-domed church inserted between the $5^{\text {th }} \mathrm{c}$. sanctuary and atrium (see Fig. 2). The state of preservation of this hybrid structure is similar to that encountered at St. John's: although all the walls and supports can be studied, most of the superstructure is missing. By reconstructing this building we can follow the development of forms and vaulting techniques during a tumultuous period in the history of Byzantine architecture.

The first reconstruction of the church was included in the publication of the first excavation report of the site. ${ }^{25}$ Some aspects of this reconstruction lack substantiation, and are too atypical stylistically to be considered credible. Almost two decades later, Fasolo proposed a more convincing reconstruction of the domed phase of the church, but which was shown, unfortunately, in a very hesitant and diagrammatic way. ${ }^{26}$ Nevertheless, this reconstruction relied on a thorough analysis of the surviving wall structures, but did not give enough attention to the secondary vault fragments of the $5^{\text {th }} \mathrm{c}$. basilica or those of the baptistery. ${ }^{27}$ In later publications there were no further attempts to investigate the vaults of the church. ${ }^{28}$

Revisiting the remains of the church, the author sought to analyse the vault remains of all the phases, and, where possible, to use these remains as a basis for the reconstruction of the complex vaulted ceiling

25 Knoll (1932) 62, fig. 73. The most puzzling aspect is the reconstruction of the domed church. The section proposed is characterised by extremely shallow proportions, seldom encountered in Early Byzantine vaulted churches.

26 Fasolo (1956) 1-22.

27 Fasolo (1956) 6.

28 Verzone (1965) 610-13; Foss (1979) 52; Castelfranchi (1999) 89. 
of St. Mary's. However, it soon became clear that in certain parts of the church, there was not enough archaeological evidence for a viable reconstruction. Several fragments provided clues for the vaults of the baptistery, and the vaulted ceilings of the side chapels of the $5^{\text {th }} \mathrm{c}$. basilica, but there was no such evidence for the main vaults of the domed church. Due to this lacuna, the reconstruction of these vaults had to rely primarily on comparisons with similar buildings elsewhere.

The following summary of the reconstruction of the vaults of St. Mary's is not meant to be exhaustive. It rather focuses on three cases where the methodology was confronted with problems associated with complex or insufficient evidence. The most challenging reconstructions were those for: the vaults over the side chapels of the $5^{\text {th }} \mathrm{c}$. basilica; the central vault of the baptistery; and the superstructure of the domed church.

The side chambers flanking the apse of the $5^{\text {th }} \mathrm{c}$. basilica included vault remains whose complex, peculiar brick structure was difficult to interpret, and, therefore, difficult to use as evidence for reconstruction. The double curvature of the fragment's surface, and the fact that it was inserted between two arches, seemed to suggest that it was part of a spherical vault. But the brick layout was not at all typical of such vaults. Bricks seemed to form horizontal courses in the springing and pitched courses nearer the top (fig. 10). It became clear that the graphic documentation of the remains was not sufficient to interpret this complex fragment. This problem was resolved with the addition of a new component to the usual methodology. Observing the layout of the surviving bricks, the author attempted to simulate the construction procedure and to continue it beyond the limits of the fragment. The most plausible simulation, and the closest one to the existing remains, consisted of setting the bricks to form radiating, arched courses whose inclination from the horizontal increases as we move from the base to the apex (fig. 11). The author designated this atypical manner of construction: 'spherical vault construction with radiating arched courses'. By prolonging the existing courses and completing the structure in this way, a pendentive dome was generated. This vault form does not only correspond to the remains, but is also perfectly adaptable to the rectangular shape of the side chapel.

An equally intriguing vault fragment provided the basis for the reconstruction of the great dome of the Baptistery. This fragment consists partly of horizontal and partly of arched brick courses (fig. 12). Both parts belong to the same surface. It is the slight curvature of the fragment that suggested that the arched courses belonged to the dome. Considered alone, however, the fragment was too small to substantiate this or to shed light on the 


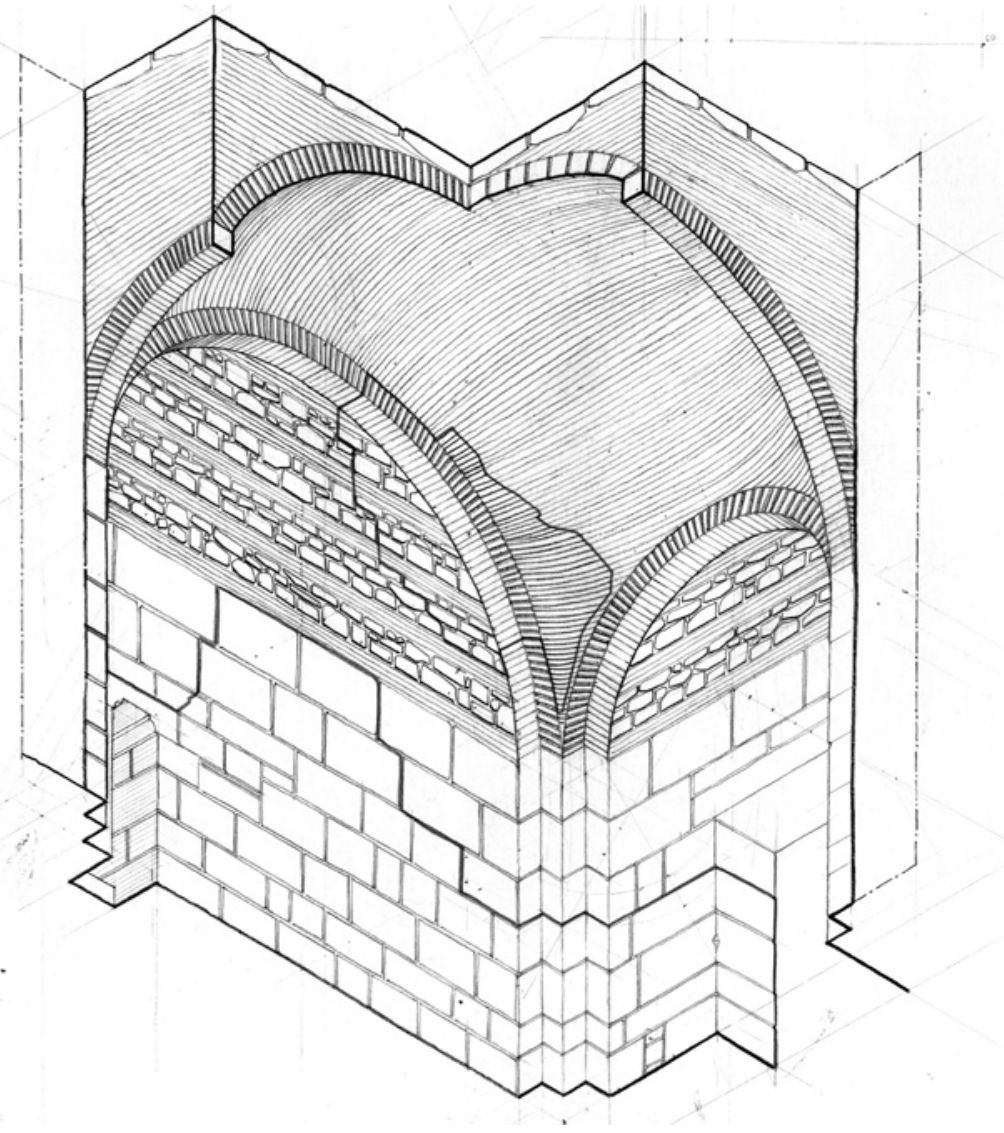

Fig. 10. Ephesus, church of St. Mary, 5th c. basilica, reconstructed axonometric of north side chamber (the surviving structure is shown with a grey outline).

structure of the dome. However, it provided an essential clue for research into similar vault structures. Focusing on vaults in which the bricks are set in arched courses, this research revealed an unknown example that helped to interpret the fragment. The only example of a vault that combines all the characteristics of our fragment proved to be the semi-dome of an unexplored Early Christian building in Corinth. ${ }^{29}$ An investigation

29 This building, situated a few hundred metres south of the forum of Corinth, is currently being investigated by the author, in collaboration with Dimitrios Athanasoulis and the twenty-fifth Ephorate of Byzantine Antiquities, who are preparing to publish their results. 


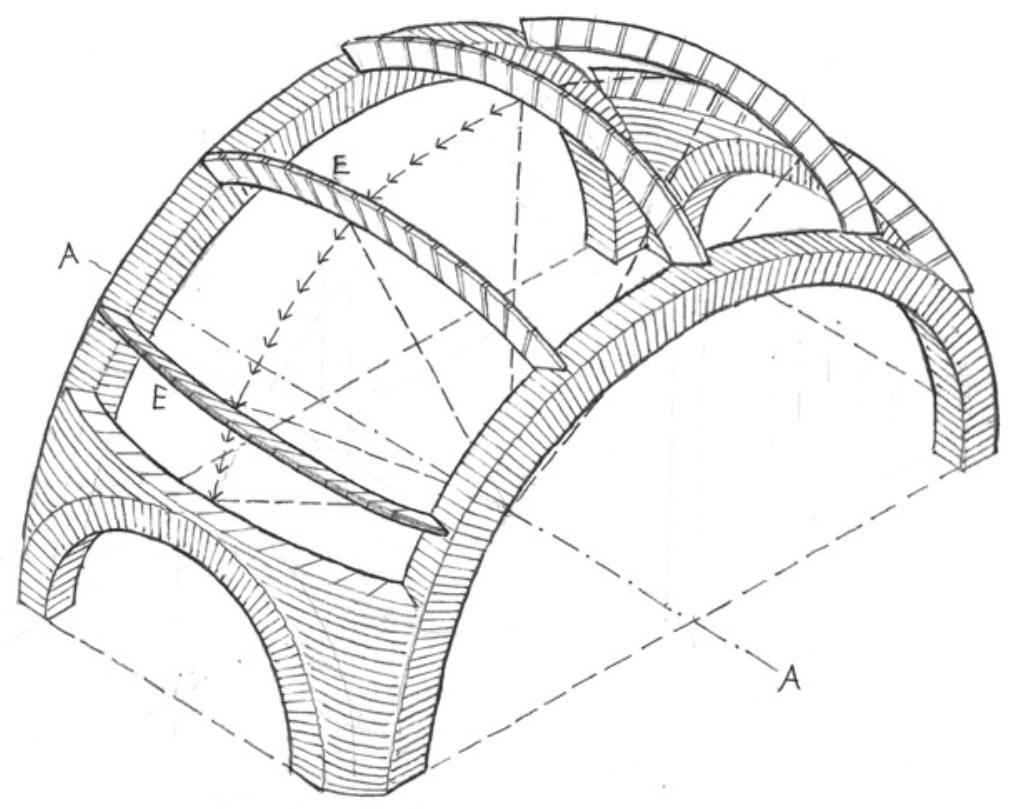

Fig. 11. Ephesus, church of St. Mary, 5th c. basilica, interpretive drawing of the vault shown in figure 9 .

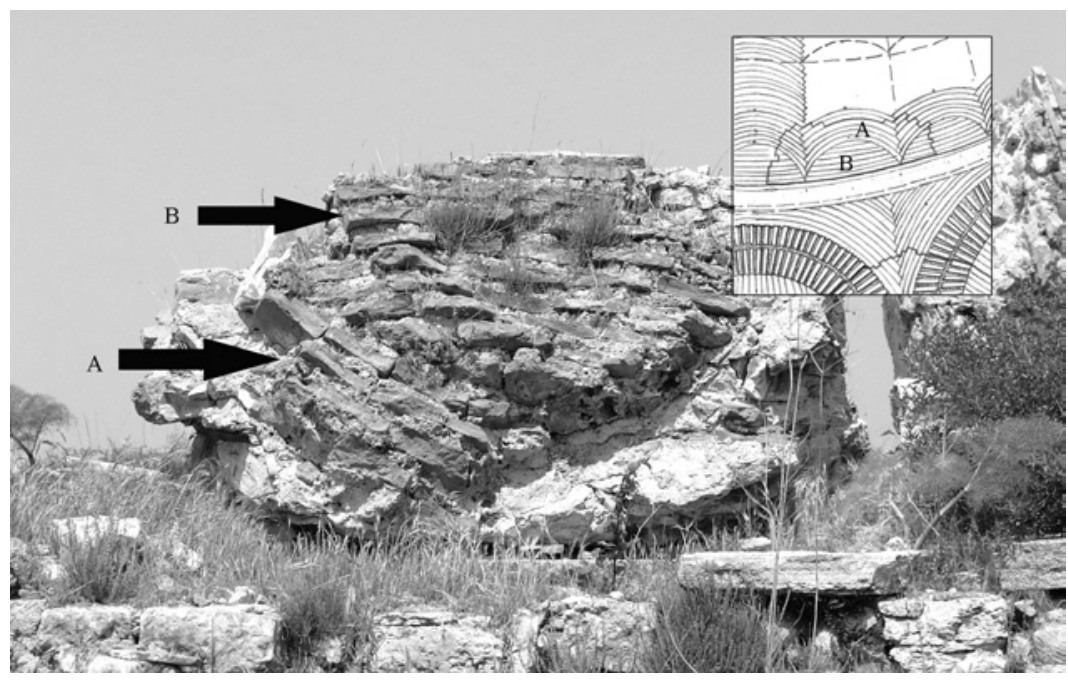

Fig. 12. Ephesus, baptistery of St. Mary, dome fragment. 


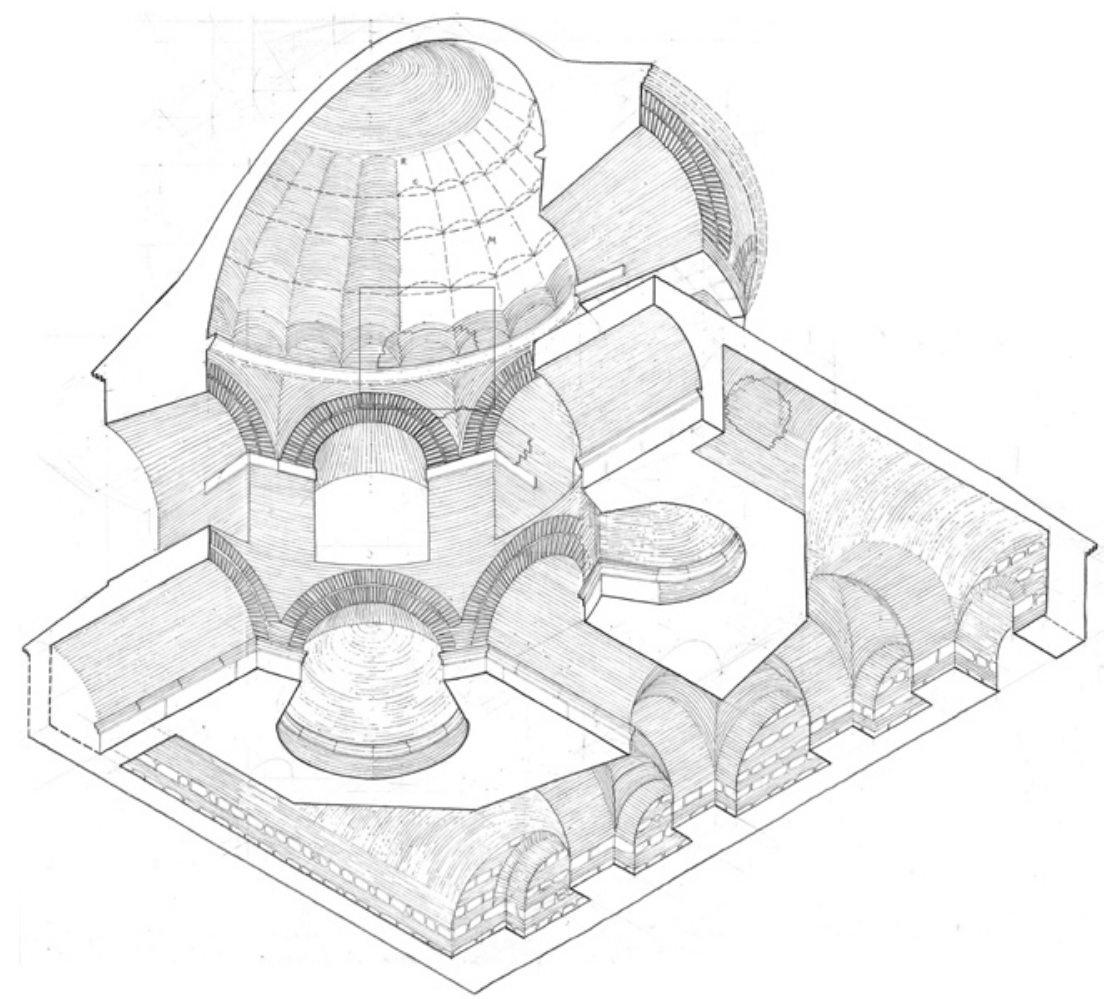

Fig. 13. Ephesus, baptistery of St. Mary, reconstruction drawing (the surviving structure, on which the reconstruction was based, is shown with a grey outline).

of this vault provided a good insight into the structure of the dome of the Baptistery of St. Mary. The vault at Corinth seems to have consisted of a series of meridional strips, growing thinner towards the top. Each of these strips was made of arched brick courses set on conical beds, with a gradually increasing inclination from the horizontal (fig. 13).

Formal comparisons played a decisive role in the reconstruction of the superstructure of the domed church of St. Mary. Although some of St. Mary's secondary vaults survive quasi intact, there is virtually no trace of the great vaults that covered the nave. The absence of vault fragments is compensated by a plan that provides many indicators for establishing its form, and thus finding comparable examples that can inform the work of reconstruction. ${ }^{30}$ The short lateral cross arms of the nave of St. Mary

30 However, the clarity of the plan has not prevented its misinterpretation by Krautheimer (1986) 249. His classification of the church alongside the church at Korykos 
are typical of a series of cross-domed basilicas, such as the church of the Koimesis at Nicaea, St. Nicholas at Myra, St. Clement at Ankara, and, above all, St. Sophia at Thessaloniki. ${ }^{31}$ These churches share a series of characteristics that also occur at St. Mary's: the cross-shaped plan of the nave, the side chambers flanking the apse, and the massiveness of the piers.

Comparisons with the above churches helped us to interpret the plan of the Ephesian church. As with them, the square bay at the crossing of the church of St. Mary was almost certainly covered by a full hemispherical dome on pendentives. It is likely that the Ephesian builders followed Early Byzantine practice, creating a series of windows in the base of the dome. As with similar cases elsewhere, the short cross-arms north and south of the crossing probably corresponded to broad arches, while the longer bays (east and west) must have been covered by barrel vaults.

If the form of the vaults of St. Mary's proved to be predictable enough, the level of these vaults, and the height of the space they covered, have both been the subject of considerable speculation. As we have seen, Knoll proposed a reconstruction of the church without galleries, attributing to it extremely squat proportions. Fasolo was the first scholar to raise the possibility of a church with galleries. He based this argument on the discovery of a series of columns that could well belong to such an upper storey. Nevertheless, in the absence of further evidence, Fasolo considered his reconstruction to be hypothetical, and the problem regarding the existence of galleries persisted.

Parallels with comparable examples elsewhere helped to re-evaluate Fasolo's find, confirming its interpretation as evidence for galleries. The parallels considered were the churches of St. Sophia at Thessaloniki, the church of the Koimesis at Nicaea, St. Nicholas at Myra, and St. Clement's at Ankara. ${ }^{32}$ The comparative analysis focused on the study of the proportional relationship between nave width and the height of the springing of the dome. It was found that, in all these examples, the height-width

(Meryemlik), the east church of Alahan Monastery, and the church at Qasr Ibn Wardan, overlooks the two most important characteristics of St. Mary: its cross-shaped dome nucleus, and the central location of its dome.

31 Buchwald (1984) 221 was the first to interpret the domed church of St. Mary as a typical cross-domed basilica, and to draw comparisons with the church of the Koimesis at Nicaea, Saint Clement in Ancara, and Saint Sophia at Thessaloniki.

32 See Schmit (1927) for a detailed survey of the Koimesis Church at Nicaea, made in 1912. St. Nicholas at Myra was published by Rott (1908) 327-40, fig. 123. For an excellent study of the church of St. Clement at Ankara, accompanied by a detailed survey, see De Jerphanion (1928) 113-43, figs. 66-68. For St. Sophia at Thessaloniki, see Theocharidou (1992) 83-99. 


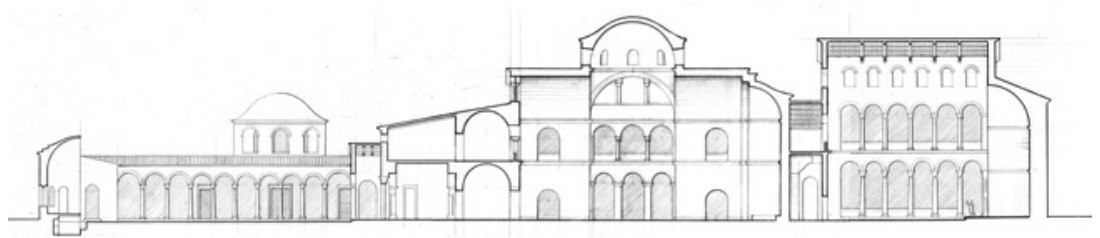

Fig. 14. Ephesus, St. Mary, domed church and surviving parts of the $5^{\text {th }} \mathrm{c}$. basilica, reconstructed section.

ratio had a limited range, between 1.5 and 1.6, regardless of whether the churches had galleries or not. ${ }^{33}$ This is markedly different from the ratio in Knoll's reconstruction, which is 1.2, in other words, an atypically squat proportion. ${ }^{34}$ This observation was used to revise Knoll's theory, reestablishing the level of the major vaults of St. Mary. If the proportions of the Ephesian church were not very different than the churches mentioned above, then its dome must have sprung approximately $19 \mathrm{~m}$ over the ground, and the supporting barrel vaults at a height of $c a .13 \mathrm{~m}$. With its four main piers reaching such a height, it seems unlikely that St. Mary did not have galleries.

The three staircases found on site constituted an additional source of evidence for the existence of galleries at St. Mary's. From an architectural point of view, the existence of so many staircases would not make sense unless they originally led to an important upper level. Of these staircases, the ones flanking the apse of the early basilica were sufficiently preserved to allow us to establish the approximate level of the gallery floor, probably around $8.6 \mathrm{~m}$ above the ground. ${ }^{35}$ Synthesising all this evidence helped to formulate the reconstructed section of the domed church, which is published here for the first time (fig. 14).

This reconstruction differs from the ones that preceded it. It tends to situate St. Mary as an architectural development typical of the period of the 7 th and the 8 th c. Whereas the Austrian reconstruction is unconvincingly peculiar, and Fasolo's reconstruction is too diagrammatic, the recent

33 Indeed, this ratio was not only observed in St. Sophia in Thessaloniki, that has galleries, but also in the Church of the Archangels at Sige, and the Church of the Koimesis at Nicaea, which did not have any.

34 Knoll and Keil (1932).

35 Our observations concerning the two east staircases were based on the survey of Knoll and Keil (1932) 36. Although the Austrian author recorded these staircases, he interpreted them in a startlingly unconvincing way as 'accesses to the roof'. 
effort resulted in a representation of St. Mary as an archetypal crossdomed church, and one very similar to St. Sophia at Thessaloniki.

One could criticise this recent reconstruction for its deviation from the methodology described in this paper, which is normally based on the analysis of vault fragments. In this particular case, however, the absence of such evidence compelled the author to rely on formal comparisons, principally with St. Sophia at Thessaloniki. Yet, this reconstruction is not unfaithful to the surviving fabric. After all, several elements, including remains of staircases, and the layout of piers, played a major role in this reconstruction. At the same time, the establishment of the dimensions and proportions of the interior space did not only rely on parallels with other buildings, but also on archaeological evidence from the site itself. Quite unlike the reconstruction attempted eighty and fifty years ago, the recent one reconciled the use of formal comparisons with site observations and the scrutiny of archaeological evidence.

\section{CONCLUSION}

The reconstruction methodology employed for the two Ephesian monuments discussed above has created a new way of looking at the vault forms employed in western Asia Minor during the Early Byzantine period. Two of its most important components are site observation and graphic recording. The latter helps to evaluate evidence from structural details that had either been misinterpreted or overlooked before. To understand these elements the author had to focus on the inner structure of these remains, looking at them in fine detail. This approach is facilitated by the dilapidated state of the monuments, which now reveal their inner structural layers. Documenting the micro features of these structures, and exploring their construction methods, provided interesting clues for the original form of the monuments.

This way of examining the monuments relies heavily on architectural knowledge and accurate draughtsmanship. Indeed, the understanding of structural forms and the elaboration of three-dimensional sketches and diagrams played a major role in this study. With the case-studies described, most of the illustrations were drawn by hand. Although computer drawings (CAD) were not used systematically, they may also prove to be a valuable tool in graphic recording and analysis. Specialised software can help produce three-dimensional drawings and help to evaluate reconstruction 
hypotheses. Three-dimensional drawings of buildings generated in this way also constitute an excellent basis for modelling the structural behaviour of historic buildings, following their graphic reconstruction.

A final note needs to be made about the 'composite' character of the reconstruction methodology employed here. This methodology required both attention to detail and the ability to see the monuments in a broad perspective, drawing parallels between far-flung structures. The combination of detailed examination and comparative analysis is rarely encountered in the bibliography: archaeological reports on individual monuments seldom make sufficient reference to comparable examples, whereas historical studies with a broader scope do not pay sufficient attention to architectural structure. This new, composite approach to the monuments makes it possible to come up with reconstructions that constitute fair interpretations of archaeological evidence, and that are credible architecturally. Of course, the interpretation of vault fragments does not always resolve all the reconstruction problems. The author's representations still involve a certain amount of speculation. Nevertheless, it remains that the combination of the graphic recording of vault fragments and their comparison with coeval buildings, has improved considerably our understanding of the original form of the buildings examined. This methodology can, therefore, play an important role in the reconstruction of a wide range of late antique and medieval monuments.

\section{BIBLIOGRAPHY}

Altunel E. (2000) "L'attivita sismica a Hierapolis e nelle zone limitrofe", in Richerche Archaeologische Turche nella valle del Lykos, edd. F. D'Andria and F. Silvestrelli (Lecce 2000) 299-308.

Buchwald H. (1984) "Western Asia Minor as a generator of architectural forms in the Byzantine Period: provincial back-wash or dynamic center of production", Jahrbuch der Österreichischen Byzantinistik 34 (1984) 200-34.

_. (1981) "The church of St John the Theologian in Alaşehir (Philadelphia)", Jahrbuch der Österreichischen Byzantinistik 30 (1981) 301-18.

Büyükkolancı M. (2000) Das Leben des Heiligen Johannes und die Johanneskirche (Selçuk 2000).

Castelfranchi M. F. (1999) "Il complesso di San Giovanni ad Efeso nel quadro dell' architettura giustinianea dell' Asia Minore", in Efeso paleocristiana e bizantina = Frühchristliches und byzantinisches Ephesos, edd. R. Pillinger, O. Kresten, F. Kritzinger, E. Russo (Vienna 1999) 89-98.

Choisy A. (1883) L'art de bâtir chez les Byzantins (Paris 1883).

Ćurčić S. (1992) "Design and structural innovation in Byzantine architecture before Hagia Sophia”, in Hagia Sophia from the Age of Justinian to the Present, edd. R. Mark and A. S. Cakmak (Cambridge 1992) 16-38. 
De Jerphanion G. (1928) “L'eglise de Saint-Clément à Angora”, in Mélanges d'archéologie anatolienne: monuments préhelléniques, gréco-romains, byzantins et musulmans de Pont, de Cappadoce et de Galatie (Mélanges de l'Université Saint-Joseph 13) (Beyrouth 1928) 113-43.

Fasolo F. (1956) "La basilica del Concilio di Efeso, con alcune note sull'architettura Romana della Valle del Meandro", Palladio 5 (1956) 1-22.

Foss C. (2002) "Pilgrimage in medieval Asia Minor", DOP 56 (2002) 129-51.

(1979) Ephesus after Antiquity: a Late Antique, Byzantine and Turkish City (Cambridge 1979).

George W. S. (1913) The Church of St. Eirene at Constantinople (London 1913).

Gough M. (1968) "Alahan Monastery, a masterpiece of Early Christian architecture”, BMMA 26.10 (1968) 455-64.

Greenewalt C. H., Cahill N. D., Stinson P. T. and Yegül F. K. (2003) The City of Sardis: Approaches in Graphic Recording (Harvard 2003).

Gros P. (2002) "L'utopie rétrospective", in Italia Antiqua, ed. A. Jacques (Paris 2002) 11-17. Hörmann H., Keil J., and Sotiriou G. A. (1951) Die Johanneskirche (Forschungen in Ephesos 4.3) (Vienna 1951).

Huerta Fernández S. (2009) "The geometry and construction of Byzantine vaults: the fundamental contribution of Auguste Choisy", in Auguste Choisy (1841-1909): l'architecture et l'art de bâtir (Textos sobre Teoría e Historia de las Construcciones 1) (Madrid 2009) 289-305.

Iacobini A. (2003-2004) "Un modello architettonico bizantino tra centro e periferia: la chiesa cupolata ad ambulacro", RendPontAcc 76 (2003-2004) 135-74.

Jewell H. H. and Hasluck F. W. (1920) The Church of Our Lady of the Hundred Gates (Panagia Hekatontapyliani) in Paros (London 1920).

Karwiese S. (1999) "Die Marienkirche und das dritte ökumenische Konzil”, in Efeso Paleochristiana e Bizantina = Frühchristliches und byzantinisches Ephesos, edd. R. Pillinger, O. Kresten, F. Kritzinger and E. Russo (Vienna 1999) 81-85.

Karydis N. (2013) "Different approaches to an Early Byzantine monument: Procopius and Ibn Battuta on the church of St. John at Ephesos", in Experiencing Byzantium, edd. C. Nesbitt and M. Jackson (Farnham 2013) 89-110.

- (2012a) "The vaults of St. John the Theologian at Ephesos: re-visualizing Justinian's church", JSAH 71.4 (2012) 524-51.

— (2012b) "A monument of Early Byzantine Sardis: architectural analysis and graphic reconstruction of Building D", AnatSt 62 (2012) 115-39.

- (2011) Early Byzantine Vaulted Construction in Churches of the Western Coastal Plains and River Valleys of Asia Minor (BAR-IS 2246) (Oxford 2011).

Knoll F. and Keil J. (1932) Die Marienkirche (Forschungen in Ephesos 4.1) (Vienna 1932).

Krautheimer R. (1986) Early Christian and Byzantine Architecture (Harmondsworth 1986).

Mainstone R. (1988) Hagia Sophia: Architecture, Structure and Liturgy of Justinian's Great Church (London 1988).

Mango C. (1978) Byzantine Architecture (Milan 1978).

Mathews T. (1971) The Early Churches of Constantinople: Architecture and Liturgy (London 1971).

Plommer H. (1962) “St. John's Church, Ephesos”, AnatSt 12 (1962) 119-29.

Rott H. (1908) Kleinasiatische Denkmäler aus Pisidien, Pamphylien, Kapadokien und Lykien (Leipzig 1908).

Schmit T. (1927) Die Koimesis-Kirche von Nikaia (Berlin 1927).

Theocharidou K. (1992) "The structure of Hagia Sophia in Thessaloniki from its construction to the present", in Hagia Sophia: From the Age of Justinian to the Present, edd. R. Mark and A. S. Cakmak (Cambridge 1992) 83-99.

Thiel A. (2005) Die Johanneskirche in Ephesos (Wiesbaden 2005).

Verzone P. (1965) “S. Giovanni e S. Maria di Efeso e la ricostruzione della città nell' VIII secolo", Corsi di Cultura Sull'Arte Ravennate e Bizantina 7 (1965) 603-26.

— (1956) "Le chiese di Hierapolis in Asia Minore", CahArch 8 (1956) 37-61. 


\section{List OF FigURES}

Fig. 1. Ephesus, church of St. John, view of the nave from the crossing.

Fig. 2. Ephesus, church of St. Mary, domed church, reconstructed axonometric.

Fig. 3. Ephesus, churches of St. John (left) and St. Mary, plans of the remains showing building phases, as well as the areas of the plan that correspond to the reconstruction of the vaults in figures $2,7,8$, and 13 .

Fig. 4. Philadelphia, church of St. John (top) and Ephesus, church of St. Mary, domed church, preliminary reconstruction hypotheses.

Fig. 5. Ephesus, church of St. John, fragments of the vault over the crossing (left) and the vault over the south bay of the transept (right).

Fig. 6. Constantinople, church of St. Eirene, sections of spherical vaults and details of their springing.

Fig. 7. Ephesus, church of St. John, reconstructed axonometric.

Fig. 8. Ephesus, church of St. John, reconstruction of the nave vaults.

Fig. 9. Ephesus, church of St. John, reconstructed section. Drawing published in Hörmann et al. (1951).

Fig. 10. Ephesus, church of St. Mary, 5th c. basilica, reconstructed axonometric of north side chamber (the surviving structure is shown with a grey outline).

Fig. 11. Ephesus, church of St. Mary, $5^{\text {th }}$ c. basilica, interpretive drawing of the vault shown in figure 9.

Fig. 12. Ephesus, baptistery of St. Mary, dome fragment.

Fig. 13. Ephesus, baptistery of St. Mary, reconstruction drawing (the surviving structure, on which the reconstruction was based, is shown with a grey outline).

Fig. 14. Ephesus, St. Mary, domed church and surviving parts of the $5^{\text {th }} \mathrm{c}$. basilica, reconstructed section. 
